\title{
Fungicide application technology for controlling the sugarcane orange rust ${ }^{1}$
}

\author{
Thales Cassemiro Alves², João Paulo Arantes Rodrigues da Cunha², \\ Rafael Marcão Tavares ${ }^{3}$, Guilherme Sousa Alves ${ }^{4}$, Sérgio Macedo Silva ${ }^{5}$
}

\section{ABSTRACT}

With the epidemic onset of the sugarcane orange rust, fungicide applications of the Strobilurins and Triazoles groups have become necessary in susceptible varieties. This study aimed at evaluating the operational conditions of fungicide application in sugarcane (SP81-3250 variety), in relation to the spray deposition on the upper canopy and the effectiveness of the orange rust control. Treatments consisted of two application volumes $\left(30 \mathrm{~L} \mathrm{ha}^{-1}\right.$ or $\left.40 \mathrm{~L} \mathrm{ha}^{-1}\right)$ and three nozzle deflection angles $\left(0^{\circ}, 90^{\circ}\right.$ or $\left.135^{\circ}\right)$, plus a ground application at the rate of $200 \mathrm{~L} \mathrm{ha}^{-1}$, sprayed with a uniform flat spray nozzle of air induction. The ground application resulted in the smallest and the greatest spray deposition on sugarcane leaves and on the soil, respectively. The aerial application at the rate of $30 \mathrm{~L} \mathrm{ha}^{-1}$, sprayed by hollow cone nozzles, at a deflection angle of $135^{\circ}$, provided the best sugarcane orange rust control.

KEYWORDS: Puccinia kuehnii (W. Krüger) E. J. Butler, Saccharum officinarum, spray deposition.

\section{INTRODUCTION}

Although the sugarcane orange rust has a recent introduction in Brazil, it has concerned farmers and technicians, due to the damages caused to the crop. This disease is caused by the Puccinia kuehnii fungus, and is currently one of the major threats to Brazilian sugarcane fields, where it was reported for the first time in the São Paulo state in 2009 (Barbasso et al. 2010).

According to Araújo et al. (2013), losses are above $40 \%$ in susceptible and intermediate varieties

\section{RESUMO}

Tecnologia de aplicação de fungicidas no controle da ferrugem alaranjada da cana-de-açúcar

Com o surgimento epidêmico da ferrugem alaranjada da cana-de-açúcar, aplicações de fungicidas dos grupos químicos Estrobilurinas e Triazóis tornaram-se necessárias para as variedades suscetíveis. Objetivou-se avaliar as condições operacionais de aplicação de fungicidas em cana-de-açúcar (variedade SP81-3250), no que se refere à deposição de calda no dossel superior e à efetividade do controle da ferrugem alaranjada. Os tratamentos consistiram de dois volumes de aplicação ( $30 \mathrm{~L} \mathrm{ha}^{-1}$ ou $\left.40 \mathrm{~L} \mathrm{ha}^{-1}\right)$ e três ângulos de deflexão das pontas $\left(0^{\circ}, 90^{\circ} \mathrm{ou} 135^{\circ}\right)$, além de uma aplicação terrestre à taxa de $200 \mathrm{~L} \mathrm{ha}^{-1}$, pulverizada por meio de pontas de jato plano uniforme de indução de ar. A aplicação terrestre resultou na menor e maior deposição nas folhas de cana-de-açúcar e no solo, respectivamente. A aplicação aérea com taxa de $30 \mathrm{~L} \mathrm{ha}^{-1}$, pulverizada por pontas de jato cônico vazio, com ângulo de deflexão de $135^{\circ}$, proporcionou o melhor controle da ferrugem alaranjada da cana-de-açúcar.

PALAVRAS-CHAVE: Puccinia kuehnii (W. Krüger) E. J. Butler, Saccharum officinarum, deposição por pulverização.

(e.g. RB72 454, SP89-1115, SP84-2025, SP813250, SP77-5181, CTC 9 and CTC 15), which are widely cultivated in Brazil. Although SP81-3250 is susceptible to orange rust, many farmers prefer to keep it in the field, due to its high yield. However, the application of fungicides is a needed management strategy, since it ensures a great disease control and improved crop yield.

Puccinia kuehnii infection is favored by high temperatures and relative air humidity in the summer and warm and cold alternations in the fall. The initial symptoms of sugarcane orange rust are small and

1. Received: Jun. 06, 2018. Accepted: Sep. 27, 2018. Published: Feb. 19, 2019. DOI: 10.1590/1983-40632019v4953386.

2. Universidade Federal de Uberlândia, Uberlândia, MG, Brasil.

E-mail/ORCID: thalescalves@hotmail.com/0000-0002-3456-0255,jpcunha@ufu.br/0000-0001-8872-3366.

3. Grupo Inquima, Uberlândia, MG, Brasil.E-mail/ORCID: rmtagro@gmail.com/0000-0001-9494-4990.

4. University of Nebraska-Lincoln, West Central Research and Extension Center, Institute of Agriculture and Natural Resources,

North Platte, NE, USA.E-mail/ORCID: guilhermeagro43@yahoo.com.br/0000-0003-4877-0293.

5. Universidade Federal dos Vales do Jequitinhonha e Mucuri, Instituto de Ciências Agrárias, Unaí, MG, Brasil.

E-mail/ORCID: sergio.macedo@ufvjm.edu.br/0000-0003-3533-517X. 
elongated yellow spots, forming a yellowish-green halo as they increase in size. Lesions rapidly progress and disrupt the leaf epidermis, forming short and oval pustules of light orange color, which are observed mainly in the region of the abaxial face of the leaves (Glynn et al. 2010).

According to Magarey et al. (2004 and 2009), the preventive application (when the leaf area reaches $5 \%$ ) of systemic and protective fungicides, such as propiconazole, cyproconazole and mancozeb, and considering the weather conditions on susceptible varieties of sugarcane to control the orange rust have been quite effective. However, depending on the crop development stage, the use of ground spraying equipment may be difficult and even unfeasible. For these reasons, more efficient applications are needed. Aerial applications can be performed in the most propitious time for the control and/or when the weather conditions do not allow the use of ground sprayers. However, it must follow well-defined technical criteria (Antuniassi et al. 2014, Oliveira et al. 2015) to ensure effectiveness and prevent environmental contamination.

Just a few studies about the efficiency of aerial pesticide application on sugarcane are described in the literature (Oliveira et al. 2011, Antuniassi et al. 2014). To determine the application quality through spray deposition, the droplet spectrum and its interactions with the crop are essential in the application technology. Among the methods used to evaluate the spray deposition and losses due to runoff and drift during a pesticide application, the spectrophotometry analysis using tracers added to the spray solution has been widely used in scientific researches (Palladini et al. 2005).

The appropriate techniques of pesticide application involve issues from the active ingredient deposition on biological targets to the reduction of pesticide losses and environmental contamination risks (Antuniassi et al. 2014, Oliveira et al. 2015). Therefore, studies related to factors such as application methods, sprayers, application rate, droplet spectrum and losses to the environment are necessary.

Thus, this study aimed to evaluate the quality of spray deposition on sugarcane plants and its efficiency on the fungicide control of orange rust provided by aerial and ground applications, using different operational conditions.

\section{MATERIAL AND METHODS}

The study was carried out in commercial areas (19 24 '45"S, 48 $09^{\circ} 46^{\prime \prime} \mathrm{W}$ and altitude of $803 \mathrm{~m}$ ) cultivated with SP81-3250 sugarcane, belonging to the Companhia Mineira de Açúcar e Álcool, in Uberaba, Minas Gerais state, Brazil, where the climate is classified as Aw (Köppen and Geiger), which is tropical wet with a dry season during the winter. The crop was planted on July 30th, 2011, spaced $1.5 \mathrm{~m}$ between rows and adapted to mechanical harvesting.

The fungicide applications were defined through inspections in the field, especially when the weather conditions were favorable for the disease development. Severity was estimated using the diagrammatic scale proposed by Amorim et al. (1987), on the sugarcane leaf +3 , with notes varying between 3 and 4, justifying the control of the disease. Two applications were carried out, with the sugarcane plants at the phenological stage of tillering (first application) and crop establishment (second application), according to Gascho \& Shih (1983). The first and second applications were respectively performed on January 29th and March 23rd, 2015, due to the high natural infection of sugarcane orange rust. Before the sugarcane was harvested on October 12th, 2015, a third application of fungicide was not necessary, because the sugarcane had completed its cycle.

In the first application, the systemic fungicide Approach ${ }^{\circledR}$ Prima was used at $0.4 \mathrm{~L} \mathrm{ha}^{-1}\left(80 \mathrm{~g} \mathrm{ha}^{-1}\right.$ of picoxystrobin $+32 \mathrm{~g} \mathrm{ha}^{-1}$ of cyproconazole), plus $0.5 \mathrm{~L} \mathrm{ha}^{-1}$ of mineral oil (Nimbus ${ }^{\mathbb{R}}$ ). In the second application, another systemic fungicide Opera ${ }^{\circledR}$ was used at $1.0 \mathrm{~L} \mathrm{ha}^{-1}\left(133 \mathrm{~g} \mathrm{ha}^{-1}\right.$ of pyraclostrobin + $50 \mathrm{~g} \mathrm{ha}^{-1}$ of epoxiconazole), plus $0.5 \mathrm{~L} \mathrm{ha}^{-1}$ of mineral oil $\left(\right.$ Assist $\left.^{\circledR}\right)$.

All fungicide treatments are detailed in Table 1. In each parcel, only one treatment was applied and 30 points were sampled. Each treatment consisted of a combination of dual factors: spray application rates $\left(30 \mathrm{~L} \mathrm{ha}^{-1}\right.$ or $\left.40 \mathrm{~L} \mathrm{ha}^{-1}\right)$ and nozzle angles $\left(0^{\circ}\right.$, $90^{\circ}$ or $135^{\circ}$ ). The angles were measured in relation to the drive line: $0^{\circ}$ (parallel and straight back) for coarse droplets; $90^{\circ}$ (perpendicular and up down) for medium droplets; and $135^{\circ}$ (forward into the wind) for fine droplets. Applications at $90^{\circ}$ were the standard application practiced by the sugar mill company, and was evaluated only in the second application. 
Table 1. Description of the treatments used in the fungicide applications on SP81-3250 sugarcane.

\begin{tabular}{|c|c|c|c|c|}
\hline \multirow{2}{*}{ Application method } & Application rate & Application speed & \multirow{2}{*}{$\begin{array}{c}\text { Nozzles } \\
\text { orientation }\end{array}$} & \multirow{2}{*}{$\begin{array}{c}\text { Work pressure } \\
\mathrm{kPa}\end{array}$} \\
\hline & $\mathrm{L} \mathrm{ha}^{-1}$ & $\mathrm{~km} \mathrm{~h}^{-1}$ & & \\
\hline Aerial & 30 & 168.0 & $135^{\circ}$ & 207 \\
\hline Aerial & 30 & 168.0 & $0^{\circ}$ & 207 \\
\hline Aerial & 40 & 168.0 & $0^{\circ}$ & 276 \\
\hline Aerial & 40 & 168.0 & $135^{\circ}$ & 276 \\
\hline Ground (standard) first application & 200 & 7.9 & - & 199 \\
\hline Aerial (standard) second application & 30 & 168.0 & $90^{\circ}$ & 207 \\
\hline Control & - & - & - & - \\
\hline
\end{tabular}

For the ground application, $200 \mathrm{~L} \mathrm{ha}^{-1}$ were sprayed through flat fan spray nozzles with air induction, producing coarse droplets. This treatment was considered because it is the most used by the company, and was evaluated only in the first application, because the sugarcane was $1.5 \mathrm{~m}$ height, not allowing the use of ground sprayers in the second application.

In ground applications, coupled to the hydraulic system of a tractor, a Falcon hydraulic sprayer was used (Jacto S/A), with $14 \mathrm{~m}$ width boom, $800 \mathrm{~L}$ tank capacity and an electronic spray controller. AI 11004-VS was the nozzle used, spaced $0.5 \mathrm{~m}$ from each other and positioned at $0.4 \mathrm{~m}$ above the canopy.

For the aerial applications, an agricultural aircraft (Embraer EMB 202A) had its spray boom equipped with 43 hollow cone nozzles (disc \#8 and core \#45), with a 950 L tank capacity, and an electronic spray controller was used. The flight took place at $3 \mathrm{~m}$ above the canopy and the distance among passes was $16 \mathrm{~m}$.

The experimental plots were sized $100 \mathrm{~m}$ in length $\mathrm{x} 48 \mathrm{~m}$ in width for the aerial applications and $100 \mathrm{~m}$ in length $\times 7 \mathrm{~m}$ in width for the ground applications, with the width corresponding to three crosswind passes by the aircraft and half-boom section of the ground sprayer, respectively. The plots that did not receive the fungicide applications sized $100 \mathrm{~m}$ in length $\mathrm{x} 9 \mathrm{~m}$ in width. The leaf samples were collected in the central area of each plot $(90 \mathrm{~m} \times 16 \mathrm{~m}$, $90 \mathrm{~m} \times 5.0 \mathrm{~m}$ and $90 \mathrm{~m} \times 7.0 \mathrm{~m}$ for aerial, ground and none application, respectively). The difference among the plot dimensions (width) was due to the application methods and area format.

The environmental conditions of temperature, relative air humidity and wind speed were monitored during the applications, using a portable weather station (Kestrel $\left.{ }^{\circledR}, 4000\right)$. The temperature stayed below $30{ }^{\circ} \mathrm{C}$, the relative air humidity higher than $55 \%$ and the wind speed oscillated from $1.11 \mathrm{~m}^{-1} \mathrm{~s}^{-1}$ to $1.66 \mathrm{~m}^{-1} \mathrm{~s}^{-1}$.

The droplet spectrum from applications was evaluated using water sensitive papers $(76 \mathrm{~mm} \mathrm{x}$ $26 \mathrm{~mm}$ ) positioned horizontally by metal holders over the canopy. Five papers were randomly distributed in each plot. Afterwards, in the laboratory, they were scanned at a 600 dpi resolution and analyzed using the droplet analyzer $\mathrm{CIR}^{\circledR}$ software, version 1.5 , for determining the following parameters: volumetric median diameter, percentage spray volume of droplets smaller than $100 \mu \mathrm{m}\left(\mathrm{V}_{100}\right)$ and relative span.

The spray depositions on sugarcane leaves and on soil were evaluated by adding brilliant blue tracer, internationally catalogued by the Food, Drug \& Cosmetic as FD\&C Blue no. 1 (Duas Rodas Industrial Ltda.), to be detected by spectrophotometry in laboratory in the concentrations of $2 \mathrm{~g} \mathrm{~L}^{-1}$ and $4 \mathrm{~g} \mathrm{~L}^{-1}$, respectively for aerial and ground applications. A correction factor was calculated to obtain a spray deposition based on the same volume, regardless of the application method.

After the application, 30 leaves $(+2,+3$ and $+4)$, according to the Kuijper system described by Bacchi (1983), were randomly collected in each experimental plot. The leaves were placed into prelabeled plastic bags. In the laboratory, $50 \mathrm{~mL}$ of distilled water were added to each plastic bag, which was swirled and shaken during $30 \mathrm{~s}$, to release the tracer from the leaves. After the tracer was suspended in the solution, a $3 \mathrm{~mL}$ aliquot from each sample bag was drawn to fill a glass cuvette. The cuvette was placed in a spectrophotometer with tungsten-halogen lamp (Biospectro), using $630 \mathrm{~nm}$ wavelength, to collect the absorbance values (Palladini et al. 2005). The sugarcane leaves were placed in a dryer at $65^{\circ} \mathrm{C}$, during $72 \mathrm{~h}$, to get the dry weight. By using 
a calibration curve for blue tracer, the deposition on leaves was expressed in weight of the tracer by dry weight of the sugarcane leaves $\left(\mu \mathrm{g} \mathrm{g}^{-1}\right)$.

The spray deposition on the soil was determined setting 15 Petri dishes on the ground in each plot, which corresponded to a collection area of $319 \mathrm{~cm}^{2}$. In the laboratory, the tracer extraction and quantification were similar to those performed for the leaves, using $10 \mathrm{~mL}$ of distilled water. In this case, the results were expressed in weight of the tracer by the collector area $\left(\mu \mathrm{g} \mathrm{cm}^{-2}\right)$.

The same sugarcane leaves collected for the spray deposition analysis were used to estimate the disease severity. The severity of the sugarcane orange rust disease was evaluated at 4, 14, 24 and 34 days after the first application and at 9, 16, 22 and 37 days after the second application. Those dates ranged according to the residual period of the fungicides. They were segmented in $25 \mathrm{~cm}$ pieces, from the middle third of each leaf, for analysis, scanned at 300 dpi resolution and finally processed using the QUANT Image Software, version 1.0.2. Severity data were used to calculate the area under the disease progress curve (Campbell \& Madden 1990), which allowed a more stable disease evaluation, being less affected by the analysis time and the environmental variations.

The data from both application dates, regarding thirty replications, were considered independent and evaluated separately, being firstly submitted to the assumption analysis tested by Kolmogorov-Smirnov (K-S) and Levene's tests, to analyze the normality of the residuals and homogeneity of the variances, respectively, at $\alpha=0.01$. All the data presented normality and variances homogeneity. Afterwards, the data were analyzed using the Student's t-test at $\alpha=0.05$, as independent samples.

\section{RESULTS AND DISCUSSION}

The lowest spray deposition on sugarcane leaves was obtained for the ground application, and the higher deposits were observed for aerial applications of $30 \mathrm{~L} \mathrm{ha}^{-1}$, regardless of the deflection angle in the first application date, and at a $90^{\circ}$ deflection in the second application date. Aerial applications of $40 \mathrm{~L} \mathrm{ha}^{-1}$ resulted in a lower deposition on leaves, if compared to $30 \mathrm{~L} \mathrm{ha}^{-1}$. However, they were also higher than those deposits from the ground application. The deflection angle did not affect the spray deposition on leaves, except when using $40 \mathrm{~L} \mathrm{ha}^{-1}$ in the second application, where the $0^{\circ}$ deflection angle increased by $29 \%$ the deposition on the leaf +2 (Table 2).

Silva (2009) and Bayer et al. (2011) observed a great liquid retention on rice leaves of the lower third of the plant canopy, when low spray volumes were applied. The authors applied $10 \mathrm{~L} \mathrm{ha}^{-1}$ using an electrostatic nozzle and $15 \mathrm{~L} \mathrm{ha}^{-1}$ using an atomizer rotating disc, and $20 \mathrm{~L} \mathrm{ha}^{-1}$ applied with hydraulic nozzles and $6 \mathrm{~L} \mathrm{ha}^{-1}$ using an atomizer rotating disc, respectively.

The application with spray volume $\left(200 \mathrm{~L} \mathrm{ha}^{-1}\right)$ resulted in a lower retention in the upper foliage, corroborating the results obtained by Bueno et al. (2013), which stated that, in applications with larger volumes, the spray droplets tend to settle in the upper part of the plant, thus decreasing the retention in the inner part of the canopy. However, higher volumes are expected to cause a higher runoff from bottom to bottom and soil, what may explain this low deposit in the volume of $200 \mathrm{~L} \mathrm{ha}^{-1}$.

It is evident that the lowest deposition on the soil was obtained by aerial applications of $30 \mathrm{~L} \mathrm{ha}^{-1}$ (Table 3). On the other hand, the ground application

Table 2. Spray deposition of tracer on leaves from aerial and ground applications of fungicide to control the sugarcane (SP81-3250) orange rust disease.

\begin{tabular}{|c|c|c|c|c|c|c|c|}
\hline \multirow{3}{*}{$\begin{array}{l}\text { Method/Application rate } \\
\qquad\left(\mathrm{L} \mathrm{ha}^{-1}\right)^{*}\end{array}$} & \multirow{3}{*}{$\begin{array}{l}\text { Deflection } \\
\text { angle }\end{array}$} & \multicolumn{6}{|c|}{ Tracer deposited on leaves $\left(\mu \mathrm{g} \mathrm{g}^{-1}\right)$} \\
\hline & & \multicolumn{3}{|c|}{ First application } & \multicolumn{3}{|c|}{ Second application } \\
\hline & & Leaf +2 & Leaf +3 & Leaf +4 & Leaf +2 & Leaf +3 & Leaf +4 \\
\hline Aerial $/ 30$ & $135^{\circ}$ & $0.0436 \mathrm{a}$ & $0.0514 \mathrm{a}$ & $0.0626 \mathrm{a}$ & $0.0135 \mathrm{~b}$ & $0.0146 \mathrm{~b}$ & $0.0201 \mathrm{~b}$ \\
\hline Aerial $/ 30$ & $0^{\circ}$ & $0.0351 \mathrm{a}$ & $0.0433 \mathrm{a}$ & $0.0528 \mathrm{a}$ & $0.0149 \mathrm{~b}$ & $0.0156 \mathrm{~b}$ & $0.0188 \mathrm{~b}$ \\
\hline Aerial $/ 40$ & $0^{\circ}$ & $0.0225 \mathrm{~b}$ & $0.0277 \mathrm{~b}$ & $0.0343 \mathrm{~b}$ & $0.0108 \mathrm{c}$ & $0.0124 \mathrm{c}$ & $0.0143 \mathrm{c}$ \\
\hline Aerial $/ 40$ & $135^{\circ}$ & $0.0250 \mathrm{~b}$ & $0.0254 \mathrm{~b}$ & $0.0358 \mathrm{~b}$ & $0.0084 \mathrm{~d}$ & $0.0098 \mathrm{c}$ & $0.0117 \mathrm{c}$ \\
\hline Ground/200 & - & $0.0128 \mathrm{c}$ & $0.0130 \mathrm{c}$ & $0.0139 \mathrm{c}$ & - & - & - \\
\hline Aerial $/ 30$ & $90^{\circ}$ & - & - & - & $0.0247 \mathrm{a}$ & $0.0281 \mathrm{a}$ & $0.0284 \mathrm{a}$ \\
\hline
\end{tabular}


of $200 \mathrm{~L} \mathrm{ha}^{-1}$ produced the highest deposition on the soil, being up to 9 times greater than that produced by aerial applications. Once again, the deposition was not affected by the deflection angles.

According to Wenneker \& Zander (2008), droplets with air included have the tendency to accumulate in the soil near the application area. Czaczyk et al. (2012) reported that coarser droplets may bounce, break and slip through the leaves and hit other targets. Bueno et al. (2013) evaluated spray losses to the soil from different carrier volumes used in aerial and ground applications on potato crop and observed higher values from the highest carrier volume without using adjuvants.

In the first application, AI 11004 air induction nozzles used in the ground application generated the coarsest droplets $(685 \mu \mathrm{m})$, as already expected (Table 4). Consequently, the lowest $\mathrm{V}_{100}$ was observed $(1.4 \%)$. Among the aerial application techniques, the deflection angle had a more important effect on the droplet spectrum than the carrier volume, especially on the volumetric median diameter and $\mathrm{V}_{100}$. The larger the deflection angle, the smaller is the volumetric median diameter and higher the $\mathrm{V}_{100}$. It means that, by using the same deflection angle, the carrier volume do not alter the droplet spectrum.
Only by using a deflection angle of $135^{\circ}$, instead of $0^{\circ}$, the volumetric median diameter decreased $32 \mu \mathrm{m}$ and $35 \mu \mathrm{m}$, whereas the $\mathrm{V}_{100}$ increased $6 \%$ and $9 \%$, respectively for $30 \mathrm{~L} \mathrm{ha}^{-1}$ and $40 \mathrm{~L} \mathrm{ha}^{-1}$.

Similar results, but different values, were observed in the second application. Once there were only aerial applications, greater volumetric median diameters $(251 \mu \mathrm{m})$ and lower $\mathrm{V}_{100}(6.43 \%)$ were generated at $30 \mathrm{~L} \mathrm{ha}^{-1}$ and $40 \mathrm{~L} \mathrm{ha}^{-1}$ carrier volumes sprayed through a $0^{\circ}$ deflection angle. Conversely, Oliveira et al. (2011) observed no differences on the volumetric median diameter from aerial applications using rotary atomizers on sugarcane crop, when they varied the carrier volume, diverging from our results.

The uniformity of the droplet spectrum from all the application conditions were similar, once no difference was observed among their relative span values, varying from 0.80 to 1.06 and from 1.11 to 1.51 , respectively in the first and second applications. According to Viana et al. (2010), lower relative span values indicate that the droplet spectrum is more homogeneous.

Bueno et al. (2011) mentioned that, although there is no exact value, the lower the $\mathrm{V}_{100}$, the smaller is the potential risk. Cunha et al. (2003) reported that a $\mathrm{V}_{100}$ up to $15 \%$ might imply in safer applications.

Table 3. Spray deposition of tracer on the soil from aerial and ground applications of fungicide to control the sugarcane (SP81-3250) orange rust disease.

\begin{tabular}{cccc}
\hline $\begin{array}{c}\text { Method/Application rate } \\
\left(\mathrm{L} \mathrm{ha}^{-1}\right)^{*}\end{array}$ & $\begin{array}{c}\text { Deflection } \\
\text { angle }\end{array}$ & \multicolumn{2}{c}{ Tracer deposited on the soil $\left(\mu \mathrm{g} \mathrm{\textrm {cm } ^ { - 2 } )}\right.$} \\
\cline { 3 - 4 } Aerial/30 & $135^{\circ}$ & First application & Second application \\
Aerial/30 & $0^{\circ}$ & $0.0319 \mathrm{~d}$ & $0.0291 \mathrm{~b}$ \\
Aerial/40 & $0^{\circ}$ & $0.0376 \mathrm{~d}$ & $0.0304 \mathrm{~b}$ \\
Aerial/40 & $135^{\circ}$ & $0.1805 \mathrm{~b}$ & $0.0546 \mathrm{a}$ \\
Ground/200 & - & $0.0936 \mathrm{c}$ & $0.0507 \mathrm{a}$ \\
Aerial/30 & $90^{\circ}$ & $0.2904 \mathrm{a}$ & - \\
\hline
\end{tabular}

* Averages followed by different letters in the column differ from each other by the Student's t-test at $\alpha=0.05$.

Table 4. Droplet spectrum from aerial and ground applications of fungicide to control the sugarcane (SP81-3250) orange rust disease.

\begin{tabular}{cccccccc}
\hline Method/Application rate & Deflection & \multicolumn{3}{c}{ First application } & \multicolumn{3}{c}{ Second application } \\
\cline { 3 - 7 }$\left(\mathrm{L} \mathrm{ha}^{-1}\right)^{1}$ & angle & VMD $(\mu \mathrm{m})$ & $\mathrm{V}_{100}(\%)$ & $\mathrm{RS}$ & $\mathrm{VMD}(\mu \mathrm{m})$ & $\mathrm{V}_{100}(\%)$ & $\mathrm{RS}$ \\
\hline Aerial$/ 30$ & $135^{\circ}$ & $145 \mathrm{c}^{* 2}$ & $15.95 \mathrm{a}$ & $0.93 \mathrm{a}$ & $154 \mathrm{c}^{* 2}$ & $15.04 \mathrm{a}$ & $1.11 \mathrm{a}$ \\
Aerial/30 & $0^{\circ}$ & $177 \mathrm{~b}^{* 3}$ & $9.69 \mathrm{~b}$ & $1.06 \mathrm{a}$ & $250 \mathrm{a}^{* 4}$ & $6.43 \mathrm{c}$ & $1.44 \mathrm{a}$ \\
Aerial/40 & $0^{\circ}$ & $180 \mathrm{~b}^{* 3}$ & $7.12 \mathrm{~b}$ & $1.00 \mathrm{a}$ & $251 \mathrm{a}^{* 4}$ & $6.55 \mathrm{c}$ & $1.51 \mathrm{a}$ \\
Aerial/40 & $135^{\circ}$ & $145 \mathrm{c}^{* 2}$ & $15.68 \mathrm{a}$ & $0.83 \mathrm{a}$ & $153 \mathrm{c}^{* 2}$ & $18.77 \mathrm{a}$ & $1.23 \mathrm{a}$ \\
Ground/200 & - & $685 \mathrm{a}^{* 5}$ & $1.40 \mathrm{c}$ & $0.80 \mathrm{a}$ & - & - & - \\
Aerial/30 & $90^{\circ}$ & - & - & - & $175 \mathrm{~b}^{* 3}$ & $9.67 \mathrm{~b}$ & $1.32 \mathrm{a}$ \\
\hline
\end{tabular}

${ }^{1}$ Averages followed by different letters in the column differ from each other by the Student's t-test at $\alpha=0.05$. ${ }^{*}$ Droplet size category provided by the CIR ${ }^{\circledR}$ software: ${ }^{2}$ fine; ${ }^{3}$ medium; ${ }^{4}$ coarse $;{ }^{5}$ extremely coarse. VMD $=$ volumetric median diameter; $\mathrm{V}_{100}$ : percentage of spray volume of droplets smaller than $100 \mu$ m; RS: relative span. 
Table 5. Area under the disease progress curve of sugarcane (SP81-3250) orange rust, in different leaves, after the aerial and ground application of fungicides.

\begin{tabular}{|c|c|c|c|c|c|c|c|}
\hline \multirow{3}{*}{$\begin{array}{l}\text { Method/Application rate } \\
\qquad\left(\mathrm{L} \mathrm{ha}^{-1}\right)^{*}\end{array}$} & \multirow{3}{*}{$\begin{array}{l}\text { Deflection } \\
\text { angle }\end{array}$} & \multicolumn{6}{|c|}{ Area under the disease progress curve } \\
\hline & & \multicolumn{3}{|c|}{ First application } & \multicolumn{3}{|c|}{ Second application } \\
\hline & & Leaf +2 & Leaf +3 & Leaf +4 & Leaf +2 & Leaf +3 & Leaf +4 \\
\hline Aerial $/ 30$ & $135^{\circ}$ & $55.55 \mathrm{~b}$ & $56.17 \mathrm{~b}$ & $75.43 \mathrm{~b}$ & $61.58 \mathrm{c}$ & $85.84 \mathrm{c}$ & $116.34 \mathrm{c}$ \\
\hline Aerial $/ 30$ & $0^{\circ}$ & $48.27 \mathrm{~b}$ & $52.33 \mathrm{~b}$ & $74.41 \mathrm{~b}$ & $62.99 \mathrm{c}$ & $91.60 \mathrm{~b}$ & $121.43 \mathrm{~b}$ \\
\hline Aerial $/ 40$ & $0^{\circ}$ & $48.60 \mathrm{~b}$ & $54.36 \mathrm{~b}$ & $75.63 \mathrm{~b}$ & $70.58 \mathrm{~b}$ & $98.01 \mathrm{~b}$ & $129.75 b$ \\
\hline Aerial $/ 40$ & $135^{\circ}$ & $50.94 \mathrm{~b}$ & $58.67 \mathrm{~b}$ & $79.78 \mathrm{~b}$ & $74.36 \mathrm{~b}$ & $100.82 \mathrm{~b}$ & $135.27 \mathrm{~b}$ \\
\hline Ground/200 & - & $53.48 \mathrm{~b}$ & $61.35 \mathrm{~b}$ & $85.76 b$ & - & - & - \\
\hline Aerial $/ 30$ & $90^{\circ}$ & - & - & - & $70.50 \mathrm{~b}$ & $103.34 \mathrm{~b}$ & $137.95 \mathrm{~b}$ \\
\hline Control & - & $108.88 \mathrm{a}$ & $126.54 \mathrm{a}$ & $177.72 \mathrm{a}$ & $117.60 \mathrm{a}$ & $164.76 \mathrm{a}$ & $192.78 \mathrm{a}$ \\
\hline
\end{tabular}

*Averages followed by different letters in the column differ from each other by the Student's t-test at $\alpha=0.05$.

Therefore, as shown in this study, aerial applications using $30 \mathrm{~L} \mathrm{ha}^{-1}$ and $40 \mathrm{~L} \mathrm{ha}^{-1}$, with hollow cone nozzles positioned at a $135^{\circ}$ deflection angle, should be preferably carried out when the weather conditions are favorable, to minimize the spray losses.

The use of small droplets must be considered mainly in the aerial applications, for providing a satisfactory coverage and uniform distribution of the spray. However, small droplets exposed to unfavorable weather conditions, such as low relative air humidity, high temperature and wind speeds, are more prone to be evaporated and lost by drift (Villalba \& Hetz 2010).

Although water sensitive papers have limitations, they are still a practical method to analyze the application quality in the field. However, this method may not be the most adequate for quantitative analyses, especially in situations where the droplets are very small.

Results from the first application showed that the application methods, in addition to the carrier volume and deflection angle in the aerial applications, had a similar severity (area under the disease progress curve) of sugarcane orange rust on leaves $+2,+3$ and +4 (Table 5). The reached indices varied from 51 to 56 for leaf +2 and from 74 to 86 for leaf +4 .

On the other hand, in the second application, the lowest disease severity was obtained from aerial applications of $30 \mathrm{~L} \mathrm{ha}^{-1}$ : on leaf +2 using $0^{\circ}$ and $135^{\circ}$ deflection angles; and on leaves +3 and +4 using a $135^{\circ}$ deflection angle. At $30 \mathrm{~L} \mathrm{ha}^{-1}$ using a $90^{\circ}$ deflection angle and at $40 \mathrm{~L} \mathrm{ha}^{-1}$ regardless of the deflection angle, there was a lower efficiency on the orange rust control than at $30 \mathrm{~L} \mathrm{ha}^{-1}$ using a $135^{\circ}$ deflection angle. These results may be a consequence of leaf deposition data, where better depositions were also observed at $30 \mathrm{~L} \mathrm{ha}^{-1}$.
As expected from both application dates, the plants that did not receive fungicide showed a higher disease severity than those that received the fungicide treatment using any application technique.

Systemic fungicides are generally effective under conditions of lower coverage, when compared with protectants fungicides. However, an adequate coverage provided by the application technology is necessary, even for systemic fungicides, mainly when they have a translaminar movement (Boller et al. 2008). According to Staier et al. (2004), the pathogen control depends on the application technology, weather conditions and fungicide efficacy.

Fungicides based on mixtures between Strobilurins and Triazoles have had a good efficacy on the sugarcane orange rust control and increased crop yield (Lenz et al. 2011, Fernándes et al. 2013). The recent appearance of orange rust have made farmers and researchers evaluate fungicides as an alternative emergency control, while susceptible varieties are not replaced by resistant ones.

The sugarcane orange rust can be controlled if the correct fungicide is selected, when the application occurs at the beginning of the epidemic growth of the disease and with a satisfactory coverage of the affected leaves (Oliveira et al. 2011).

\section{CONCLUSIONS}

1. The ground application with extremely coarse droplets provides a droplet spectrum environmentally safer (predominance of extremely coarse droplets and low percentage of fine droplets). However, it results in the smallest spray deposition on sugarcane leaves and a higher spray loss to the soil; 
2. The aerial application of $30 \mathrm{~L} \mathrm{ha}^{-1}$ of carrier volume sprayed through hollow cone nozzles at $0^{\circ}$ and $135^{\circ}$ deflection angles provides the best control of the sugarcane orange rust. As the $0^{\circ}$ deflection angle produces coarser droplets and a lower percentage of fine droplets than at $135^{\circ}$, it is a viable option to provide safer applications and a satisfactory sugarcane orange rust control.

\section{ACKNOWLEDGMENTS}

The authors thank the Companhia Mineira de Açúcar e Álcool (CMAA) - Vale do Tijuco, Aeroagrícola and Coordenação de Aperfeiçoamento de Pessoal de Nível Superior (Capes), for supporting this study.

\section{REFERENCES}

AMORIM, L. et al. Metodologia de avaliação de ferrugem da cana-de-açúcar (Puccinia melanocaphala). Boletim Técnico Copersucar, v. 39, n. 1, p. 13-16, 1987.

ANTUNIASSI, U. R. et al. Spray drift from aerial application. Aspects of Applied Biology, v. 122, n. 1, p. 279-284, 2014.

ARAÚJO, K. L. et al. Resistência genotípica e monitoramento da favorabilidade para ocorrência da ferrugem alaranjada da cana-de-açúcar. Summa Phytopathologica, v. 39, n. 4, p. 271-275, 2013.

BACCHI, O. S. Botânica da cana-de-açúcar. In: ORLANDO FILHO, J. Nutrição e adubação da cana-deaçúcar no Brasil. Piracicaba: Planalsucar, 1983. p. 25-37.

BARBASSO, D. et al. First report of Puccinia kuehnii, causal agent of orange rust of sugarcane, in Brazil. Plant Disease, v. 94, n. 9, p. 1170-1170, 2010.

BAYER, T. et al. Equipamentos de pulverização aérea e taxas de aplicação de fungicida na cultura do arroz irrigado. Revista Brasileira de Engenharia Agrícola e Ambiental, v. 15, n. 2, p. 192-198, 2011.

BOLLER, W. et al. Tecnologia de aplicação de fungicidas: parte II. Revisão Anual de Patologia de Plantas, v. 16, n. 1, p. 85-132, 2008.

BUENO, M. R. et al. Deposição de calda na aplicação aérea e terrestre de fitossanitário na cultura da batata. Engenharia Agrícola, v. 33, n. 6, p. 1210-1222, 2013.

BUENO, M. R. et al. Estudo do espectro de gotas produzidas nas pulverizações aérea e terrestre na cultura da batata. Revista de Ciências Agrárias, v. 54, n. 3, p. $225-$ 234, 2011.
CAMPBELL, C. L.; MADDEN, L. V. Introduction to plant disease epidemiology. New York: John Wiley \& Sons, 1990.

CUNHA, J. P. A. R. et al. Avaliação de estratégias para redução da deriva de agrotóxicos em pulverizações hidráulicas. Planta Daninha, v. 21, n. 2, p. 325-332, 2003.

CZACZYK, Z. et al. Droplet size classification of air induction flat fan nozzles. Journal of Plant Protection Research, v. 52, n. 4, p. 415-420, 2012.

FERNÁNDES, M. da S. et al. Produtividade, açúcar e brotação de cana-de-açúcar submetida a fungicidas e maturadores. Nucleus, v. 10, n. 2, p. 323-338, 2013.

GASCHO, G. J.; SHIH, S. F. Sugar cane. In: TEARE, I. D.; PEET, M. M. (Eds.). Crop-water relations. New York: Wiley-Interscience, 1983. p. 445-479.

GLYNN, N. C. et al. PCR assay for the sugarcane rust pathogens Puccinia kuehnii and P. melanocephala and detection of a SNP associated with geographical distribution in P. kuehnii. Plant Pathology, v. 59, n. 4, p. 703-711, 2010.

LENZ, G. et al. Severidade de doenças e manutenção da área foliar verde em função da aplicação de micronutrientes e fungicidas em trigo. Summa Phytopathologica, v. 37, n. 2, p. 119-124, 2011.

MAGAREY, R. C. et al. Yield losses caused by leaf diseases: 1999 and 2003 selection trial analyses. Sugar Cane International, v. 27, n. 4, p. 135-142, 2009.

MAGAREY, R. C.; NEILSEN, W. A.; BULL, J. I. Environmental requirements for spore germination in three sugarcane leaf pathogens. In: HOGARTH, D. M. Proceedings of the conference of the Australian Society of Sugar Cane Technology. Queensland: PK, 2004. 1 CD-ROM.

OLIVEIRA, R. B. et al. Spray adjuvant characteristics affecting agricultural spraying drift. Engenharia Agrícola, v. 35, n. 1, p. 109-116, 2015.

OLIVEIRA, V. A. B. et al. Desempenho de bicos rotativos e hidráulicos na aplicação aérea de fungicidas em canade-açúcar. Revista Brasileira de Tecnologia Aplicada nas Ciências Agrárias, v. 4, n. 3, p. 111-122, 2011.

PALLADINI, L. A. et al. Choice of tracers for the evaluation of spray deposits. Scientia Agricola, v. 62, n. 5, p. 440-445, 2005.

SILVA, T. M. B. Tecnologia de aplicação aérea de fungicidas na cultura do arroz irrigado. 2009. $63 \mathrm{f}$. Dissertação (Mestrado em Agronomia) - Centro de Ciências Rurais, Universidade Federal de Santa Maria, Santa Maria, 2009. 
STAIER, T. N.; MARGAREY, R. C.; FINLAYSON, W. A. Meteorological data collection, analysis and sugarcane disease forecasting for orange rust. In: HOGARTH, D. M. Proceedings of the conference of the Australian Society of Sugar Cane Technology. Mackay: PK, 2004. p. 25-25.

VIANA, R. G. et al. Distribuição volumétrica e espectro de gotas de pontas de pulverização de baixa deriva. Planta Daninha, v. 28, n. 2, p. 439-446, 2010.
Villalba, J.; HetZ, E. Deriva de productos agroquímicos: efecto de las condiciones ambientales. In: MAGDALENA, J. C. et al. Tecnología de aplicación de agroquímicos. Buenos Aires: INTA, 2010. p. 45-54.

WENNEKER, M.; ZANDER, J. C. V. de. Drift reduction in orchard spraying using a cross flow sprayer equipped with reflection shields (Wanner) and air injection nozzles. CIGR Journal, v. 10, n. 1, p. 1-10, 2008. 